\title{
Abundance and composition of ammonia-oxidizing bacteria and ammonia-oxidizing archaea communities of an alkaline sandy loam
}

\author{
Ju-pei Shen, ${ }^{1,2}$ Li-mei Zhang, ${ }^{1}$ Yong-guan Zhu, ${ }^{1 *}$ \\ Jia-bao Zhang, ${ }^{3}$ Ji-zheng $\mathrm{He}^{1 *}$ \\ ${ }^{1}$ State Key Laboratory of Urban and Regional Ecology, \\ Research Centre for Eco-environmental Sciences, \\ Chinese Academy of Sciences, Beijing 100085, China. \\ ${ }^{2}$ Graduate School, Chinese Academy of Sciences, \\ Beijing 100049, China. \\ ${ }^{3}$ State Experimental Station of Agro-Ecosystem in \\ Fengqiu, State Key Laboratory of Soil and Sustainable \\ Agriculture, Institute of Soil Science, Chinese Academy \\ of Sciences, Nanjing 210008, China.
}

\section{Summary}

The abundance and composition of soil ammoniaoxidizing bacteria (AOB) and ammonia-oxidizing archaea (AOA) communities under different long-term (17 years) fertilization practices were investigated using real-time polymerase chain reaction and denaturing gradient gel electrophoresis (DGGE). A sandy loam with $\mathrm{pH}\left(\mathrm{H}_{2} \mathrm{O}\right)$ ranging from 8.3 to 8.7 was sampled in years 2006 and 2007, including seven fertilization treatments of control without fertilizers (CK), those with combinations of fertilizer nitrogen $(\mathrm{N})$, phosphorus (P) and potassium (K): NP, NK, PK and NPK, half chemical fertilizers NPK plus half organic manure (1/2OMN) and organic manure (OM). The highest bacterial amoA gene copy numbers were found in those treatments receiving $\mathrm{N}$ fertilizer. The archaeal amoA gene copy numbers ranging from $1.54 \times 10^{7}$ to $4.25 \times 10^{7}$ per gram of dry soil were significantly higher than those of bacterial amoA genes, ranging from $1.24 \times 10^{5}$ to $2.79 \times 10^{6}$ per gram of dry soil, which indicated a potential role of AOA in nitrification. Ammonia-oxidizing bacteria abundance had significant correlations with soil $\mathrm{pH}$ and potential nitrification rates. Denaturing gradient gel electrophoresis patterns revealed that the fertilization resulted in an obvious change of the $А O B$ community, while no significant change of the AOA community

Received 22 November, 2007; accepted 26 January, 2008. *For correspondence. E-mail jzhe@rcees.ac.cn; ygzhu@rcees.ac.cn; Tel. (+86) 10 62849788; Fax (+86) 1062923563. was observed among different treatments. Phylogenetic analysis showed a dominance of Nitrosospiralike sequences, while three bands were affiliated with the Nitrosomonas genus. All AOA sequences fell within cluster $\mathbf{S}$ (soil origin) and cluster $\mathrm{M}$ (marine and sediment origin). These results suggest that longterm fertilization had a significant impact on $А O B$ abundance and composition, while minimal on AOA in the alkaline soil.

\section{Introduction}

The oxidation of ammonia to nitrate via nitrite, i.e. nitrification, is of fundamental importance in the global nitrogen $(\mathrm{N})$ cycle. While the general biogeochemistry of autotrophic ammonia-oxidizing bacteria (AOB) is well understood, there have been a number of recent discoveries associated with nitrification. For example, two complementary metagenomic studies of seawater (Venter et al., 2004) and soil (Treusch et al., 2005) revealed the presence of ammonia monooxygenase $(a m o A)$ gene derived from uncultivated Crenarchaeota, suggesting a potential capacity for ammonia oxidation. The potential of archaeal ammonia oxidation was demonstrated by the isolation of Nitrosopumilus maritimus from a marine aquarium and its close phylogenetic relationship to environmental marine crenarchaeal sequences indicates that ammonia-oxidizing archaea $(\mathrm{AOA})$ may be important to the global nitrogen cycle (Könneke et al., 2005).

The diversity of $A O B$ has been shown to shift in response to agricultural management practices (Bruns et al., 1999; Avrahami and Conrad, 2003). Stephen and colleagues (1996) detected a trend showing domination by Nitrosospira cluster 3 in neutral pH agricultural plots towards Nitrosospira cluster 2 in acidic soils. Molecular analysis of Deepskye soil in southern Scotland indicated no effect of nitrogen deposition on $A O B$ communities, and the AOB composition contained both Nitrosomonas europaea and Nitrosospira in year 2002, while only Nitrosospira could be detected in year 2003 (Schmidt et al., 2007). These studies showed a possible change in abundance and community of $\mathrm{AOB}$ in response to the temporal variation and environmental factors. 
Table 1. Chemical properties and potential nitrification rate (PNR) of a sandy loam soil under different fertilization treatments.

\begin{tabular}{llllll}
\hline Treatment & $\begin{array}{l}\mathrm{pH} \\
\left(\mathrm{H}_{2} \mathrm{O}\right)\end{array}$ & $\begin{array}{l}\text { Organic carbon } \\
\left(\mathrm{g} \mathrm{kg}^{-1}\right)\end{array}$ & $\begin{array}{l}\mathrm{NH}_{4}^{+}-\mathrm{N} \\
\left(\mathrm{mg} \mathrm{kg}^{-1}\right)\end{array}$ & $\begin{array}{l}\mathrm{NO}_{3}^{-}-\mathrm{N} \\
\left(\mathrm{mg} \mathrm{kg}^{-1}\right)\end{array}$ & $\begin{array}{l}\text { PNR } \\
\left(\mu \mathrm{NO}_{2}^{-}-\mathrm{N} \mathrm{g}^{-1} \mathrm{dry} \mathrm{soil} \mathrm{h}^{-1}\right)\end{array}$ \\
\hline $\mathrm{CK}$ & $8.65 \pm 0.05 \mathrm{c}$ & $4.21 \pm 0.26 \mathrm{a}$ & $6.14 \pm 3.58 \mathrm{a}$ & $6.46 \pm 3.25 \mathrm{a}$ & $0.13 \pm 0.03 \mathrm{a}$ \\
$\mathrm{NP}$ & $8.34 \pm 0.04 \mathrm{a}$ & $5.52 \pm 0.17 \mathrm{c}$ & $4.25 \pm 0.40 \mathrm{a}$ & $33.4 \pm 0.8 \mathrm{c}$ & $2.54 \pm 0.55 \mathrm{~d}$ \\
$\mathrm{NK}$ & $8.41 \pm 0.09 \mathrm{ab}$ & $4.30 \pm 0.23 \mathrm{a}$ & $5.35 \pm 1.48 \mathrm{a}$ & $35.2 \pm 10.3 \mathrm{c}$ & $1.54 \pm 0.56 \mathrm{c}$ \\
$\mathrm{PK}$ & $8.51 \pm 0.04 \mathrm{~b}$ & $4.86 \pm 0.13 \mathrm{~b}$ & $4.74 \pm 0.57 \mathrm{a}$ & $2.36 \pm 0.39 \mathrm{a}$ & $0.09 \pm 0.03 \mathrm{a}$ \\
$\mathrm{NPK}$ & $8.37 \pm 0.07 \mathrm{a}$ & $5.71 \pm 0.24 \mathrm{c}$ & $4.65 \pm 0.64 \mathrm{a}$ & $22.6 \pm 2.7 \mathrm{~b}$ & $1.13 \pm 0.32 \mathrm{~b}$ \\
$1 / 2 \mathrm{OMN}$ & $8.47 \pm 0.05 \mathrm{~b}$ & $7.40 \pm 0.46 \mathrm{~d}$ & $5.20 \pm 0.45 \mathrm{a}$ & $10.9 \pm 1.1 \mathrm{a}$ & $0.34 \pm 0.08 \mathrm{a}$ \\
OM & $8.48 \pm 0.01 \mathrm{~b}$ & $9.68 \pm 0.67 \mathrm{e}$ & $5.45 \pm 0.43 \mathrm{a}$ & $4.91 \pm 3.63 \mathrm{a}$ & $0.14 \pm 0.08 \mathrm{a}$ \\
\hline
\end{tabular}

a. Treatment: control without fertilization (CK), fertilizers NP (NP), fertilizers NK (NK), fertilizers PK (PK), fertilizers NPK (NPK), half chemical fertilizers NPK plus half organic manure $(1 / 2 \mathrm{OMN})$ and organic manure $(\mathrm{OM})$.

Values are mean $\pm \mathrm{SD}(n=4)$. Values within the same column followed by the same letter do not differ at $P<0.05$.

Following the discovery of the archaeal amoA gene to be ubiquitous in the ocean, the study on $A O A$ in the terrestrial environment has become more compelling than before. For example, real-time polymerase chain reaction (PCR) analyses showed that transcripts of amoA-like genes can be detected in soil and that transcription was probably induced in response to ammonia addition (Treusch et al., 2005). A study in the North Sea revealed the abundance of archaeal amoA genes was one to two orders of magnitude higher than those of bacterial nitrifiers (Wuchter et al., 2006). Similar results were obtained in soil ecosystems, where AOA dominate in numbers over $\mathrm{AOB}$, as much as three orders of magnitude depending on soil type measured (Leininger et al., 2006). The pH values of the soil samples used in that study ranged from 5.5 to 7.3 , mostly in the neutral $\mathrm{pH}$ range. In a previous study, we investigated the abundance and community structure of $A O B$ and $A O A$ in acid soil samples with $\mathrm{pH}$ ranging from 3.7 to 6.0 , and found that there was a pronounced difference in AOA composition among different fertilization treatments and higher copy numbers of archaeal amoA gene than bacterial amoA gene (He et al., 2007). Phylogenetic analysis of several hundred archaeal $a m O A$ sequences revealed diverse and distinct $A O A$ communities associated with different habitats and sampling sites, with little overlap between water columns and sediments (Francis et al., 2005). Therefore, considering the abundance of $A O A$ in the environment, it is also important to identify the factors that influence the community abundance and structure of $\mathrm{AOA}$ in soils.

Nitrification in the alkaline soil is different from acid and neutral soils (Sigunga et al., 2002), and alkaline soil is widely distributed in northern China. However, knowledge of the interactions between environmental conditions and the communities of AOB and AOA in alkaline arable soil is particularly scarce. In this study, we collected alkaline soil samples from a 17-year fertilization experimental station located in northern China in April 2006 and April 2007, and examined the abundance and composition of $A O B$ and $A O A$ under different fertilization practices. It aimed to assess the relationship between the abundance and composition of $A O B$ and $A O A$, and the soil characteristics associated with different fertilization regimes using realtime PCR and denaturing gradient gel electrophoresis (DGGE) approaches.

\section{Results}

\section{Soil chemical properties and potential nitrification rates}

Soil $\mathrm{pH}$ values ranged from 8.34 to 8.65 with some changes among the different fertilizer treatments (Table 1). Control without fertilizer (CK) had the highest $\mathrm{pH}$ of 8.65 , while the lowest $\mathrm{pH}$ values were recorded from 8.34 to 8.41 in all the mineral fertilizer treatments receiving mineral nitrogen $(\mathrm{N})$ fertilizer (NP, NK and NPK; $\mathrm{P}=$ phosphorus; $\mathrm{K}=$ potassium). No significant difference in soil $\mathrm{NH}_{4}{ }^{+}-\mathrm{N}$ content was found among the treatments (Table 1). There was a higher ratio of $\mathrm{NO}_{3}{ }^{-}-\mathrm{N}$ to $\mathrm{NH}_{4}{ }^{+}-\mathrm{N}$ in the mineral $\mathrm{N}$ treatments [NP, NK, NPK and half chemical fertilizers NPK plus half organic manure $(1 / 2 \mathrm{OMN})]$ from 7.76 to 2.09, while the ratio in CK was 1.05. The ratio in PK and organic manure (OM) treatments were below 1.0 , as 0.50 and 0.90 respectively.

Potential nitrification rates (PNR) provide an independent estimate of the abundance of ammonia oxidizers (Table 1). The highest potential nitrification rates were recorded in NP and 28 times higher than PK. The second and third were in the NK and NPK treatments, respectively, and the lowest were recorded in the other treatments (1/2OMN, OM, CK and PK). Potential nitrification rates had a positive correlation with soil $\mathrm{NO}_{3}{ }^{-}-\mathrm{N}$ content $(r=0.929, n=7, P<0.01)$, but a negative correlation with soil $\mathrm{pH}(r=-0.784, n=7, P<0.05)$.

\section{Abundance of bacteria in the soil}

The real-time PCR assays, targeting bacterial 16S rRNA gene, yielded $3.39 \times 10^{9}-1.23 \times 10^{10}$ copy numbers per gram of dry soil in 2006 (Fig. 1). There was no significant 


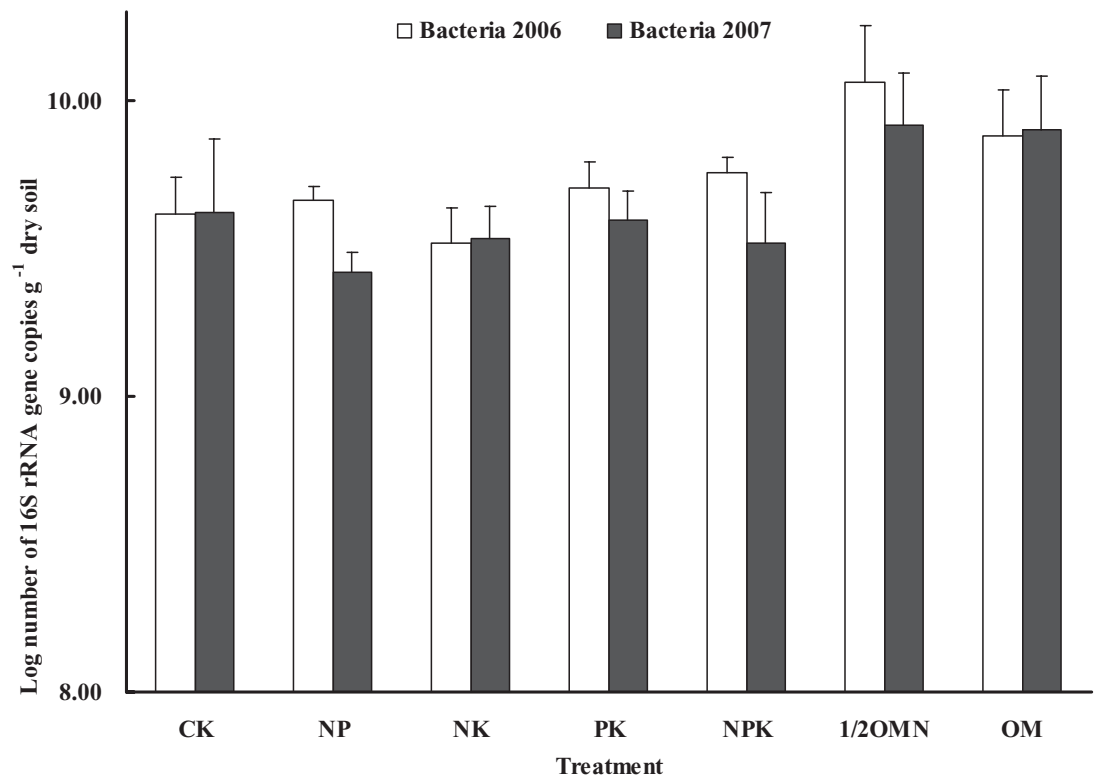

Fig. 1. Bacterial $16 \mathrm{~S}$ rRNA gene copy numbers in 2006 and 2007 under different fertilization treatments. Treatment: control without fertilization (CK), fertilizers NP (NP), fertilizers NK (NK), fertilizers PK (PK), fertilizers NPK (NPK), half chemical fertilizers NPK plus half organic manure $(1 / 2 \mathrm{OMN})$ and organic manure (OM). difference in the bacterial 16S rRNA gene copy numbers between years 2006 and 2007 . The number of bacterial 16S rRNA gene copies in the 1/2OMN treatment in 2006 was significantly higher than other treatments. However, in 2007 two treatments (1/2OMN and OM) were significantly higher than other treatments. Additionally, there was a significant correlation between soil organic carbon and bacterial 16S rRNA gene copy numbers $(r=0.769$, $n=7, P<0.05)$.

\section{Abundance of $A O B$ and $A O A$ in the soil}

Abundance of $A O B$ and $A O A$ were estimated by quantifying their respective amoA gene copy numbers. The highest bacterial amoA gene copy numbers in 2006 at $2.76 \times 10^{6}$ copies per gram of dry soil were found in the
NP treatment, followed by the NK, NPK and 1/2OMN treatments, and the lowest appeared in the CK treatments, with the NP treatment 22.5 times higher than the CK treatment (Fig. 2). The bacterial amoA gene copy numbers in treatments receiving $\mathrm{N}$ fertilizer were significantly higher than other treatments. No significant differences were found between the CK and PK treatments. In contrast to the abundance of $A O B$, no significant differences in the archaeal amoA gene copy numbers were observed among all the treatments (Fig. 2). The archaeal amoA gene copy numbers in different treatments, ranging from $1.54 \times 10^{7}$ to $4.25 \times 10^{7}$ per gram of dry soil, were higher than those of bacterial amoA gene copy numbers, ranging between $1.24 \times 10^{5}$ and $2.79 \times 10^{6}$ per gram of dry soil. The ratios of $A O A$ to $A O B$ ranged from 7.75 to over 276 in the treatments, and were significantly higher

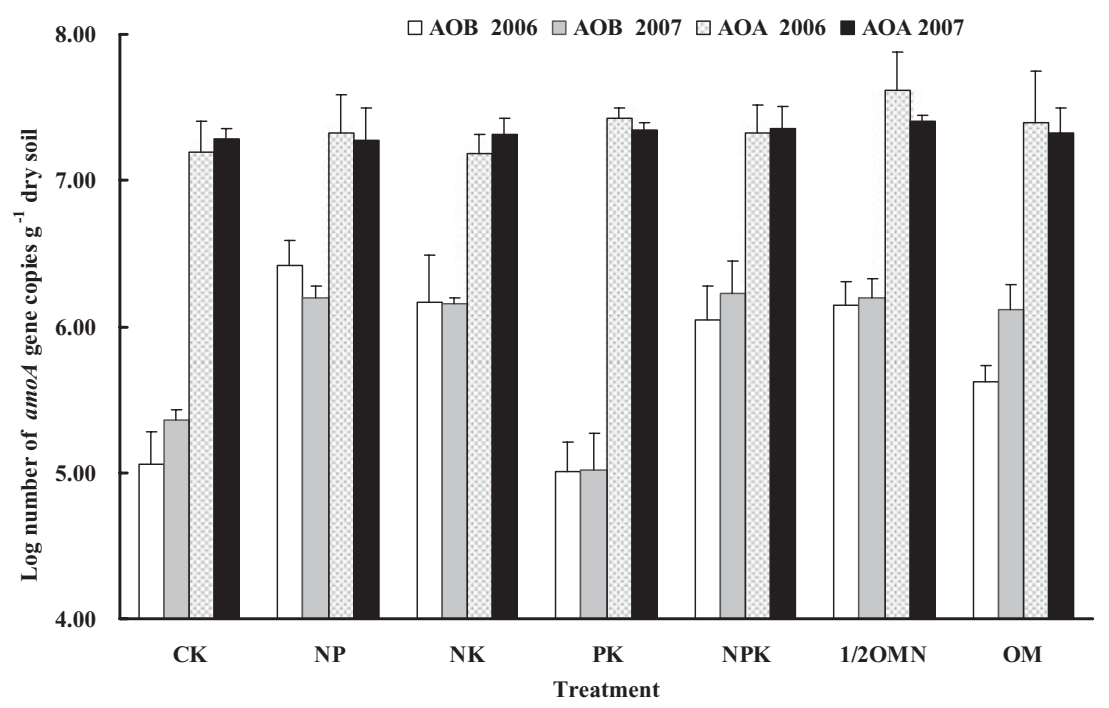

Fig. 2. Abundance of bacterial and archaeal $a m o A$ genes in 2006 and 2007 under different fertilization treatments. Treatment: control without fertilization (CK), fertilizers NP (NP), fertilizers NK (NK), fertilizers PK (PK), fertilizers NPK (NPK), half chemical fertilizers NPK plus half organic manure $(1 / 2 \mathrm{OMN})$ and organic manure $(\mathrm{OM})$. 


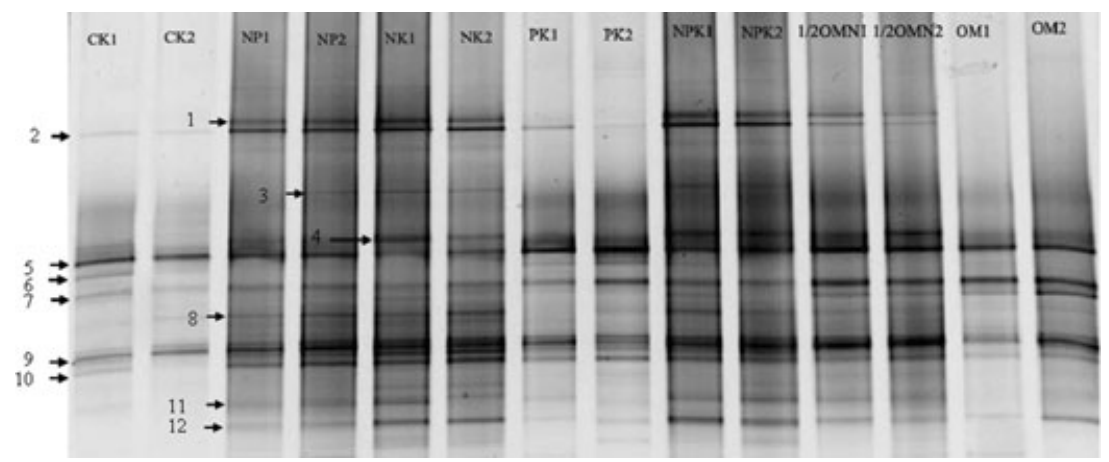

Fig. 3. Denaturing gradient gel electrophoresis profiles of bacterial amoA gene under different fertilization treatments. Band position was highlighted with a numbered arrow. Treatment: control without fertilization (CK), fertilizers NP (NP), fertilizers NK (NK), fertilizers PK (PK), fertilizers NPK (NPK), half chemical fertilizers NPK plus half organic manure (1/2OMN) and organic manure $(\mathrm{OM})$.

in the CK and PK treatments (128 and 276 respectively). The data in 2007 showed a significantly positive correlation with those in 2006 for $\mathrm{AOB}(r=0.911, n=7, P<0.01)$ and AOA ( $r=0.790, n=7, P<0.05)$. In addition, there was no significant difference in the amo $A$ gene copy numbers of $A O B$ or $A O A$ in different treatments between the two years.

\section{Genetic profiling of bacterial and archaeal amoA genes}

The community structure of $\mathrm{AOB}$ and $\mathrm{AOA}$ were analysed by DGGE. Denaturing gradient gel electrophoresis profiles of three replicates for each treatment indicated good reproducibility and two of three replicates were shown in this study (Figs 3 and 4). Bands with the same mobility in the DGGE gels were marked with the same number and excised for phylogenetic analysis.
Denaturing gradient gel electrophoresis patterns of AOB showed a clear variation with different fertilizer treatments and 12 different bands in total were detected (Fig. 3). Band 3 was unique to all the mineral $\mathrm{N}$ fertilizer treatments except in NP1. Those treatments that received $\mathrm{N}$ fertilizer (NP, NK, NPK and 1/2OMN) showed a more diverse banding pattern with additional bands 1-2, 8 and 11 , than the OM treatments. Although some bands $(2,5$, $7,9,10)$ were present in the profiles of most treatments, their intensity was different. For example, band 2 had the highest intensity in those mineral $\mathrm{N}$ fertilizer treatments, while slight in the $\mathrm{CK}$ and $1 / 2 \mathrm{OMN}$ treatments, disappeared in the OM treatment. Shannon index is commonly used to characterize species diversity in a community. The mineral $\mathrm{N}$ fertilizer treatments (NP, NK, NPK) had higher Shannon index values than any other treatments (Table 2). There was a significant correlation between the

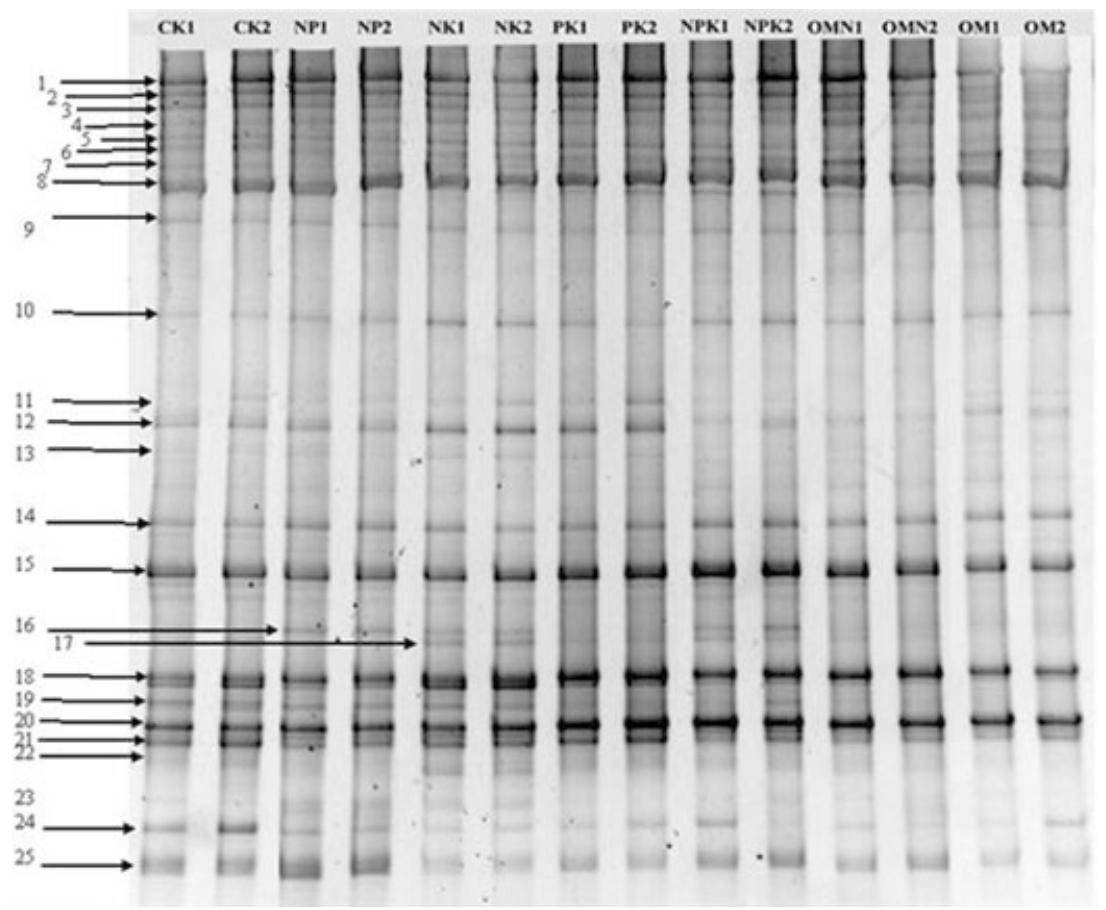

Fig. 4. Denaturing gradient gel electrophoresis profiles of archaeal amoA gene under different fertilization treatments. Band position was highlighted with a numbered arrow. Treatment: control without fertilization (CK), fertilizers NP (NP), fertilizers NK (NK), fertilizers PK (PK), fertilizers NPK (NPK), half chemical fertilizers NPK plus half organic manure $(1 / 2 \mathrm{OMN})$ and organic manure $(\mathrm{OM})$. 
Table 2. Diversity properties of $A O B$ and $A O A$ calculated from DGGE band pattern data under different fertilization treatments.

\begin{tabular}{lllll}
\hline & \multicolumn{2}{c}{ AOB } & & AOA \\
\cline { 2 - 3 } Treatment & Shannon $(H)$ & Evenness $(E)$ & Shannon $(H)$ & Evenness $(E)$ \\
\hline CK & $1.72 \pm 0.05 \mathrm{a}^{\mathrm{a}}$ & $0.96 \pm 0.03$ & $2.99 \pm 0.05 \mathrm{~b}$ & $0.95 \pm 0.01$ \\
NP & $2.35 \pm 0.02 \mathrm{~d}$ & $0.98 \pm 0.01$ & $3.03 \pm 0.04 \mathrm{~b}$ & $0.95 \pm 0.01$ \\
NK & $2.45 \pm 0.01 \mathrm{e}$ & $0.98 \pm 0.00$ & $3.10 \pm 0.02 \mathrm{c}$ & $0.96 \pm 0.01$ \\
PK & $2.00 \pm 0.09 \mathrm{~b}$ & $0.96 \pm 0.04$ & $3.04 \pm 0.02 \mathrm{~b}$ & $0.97 \pm 0.01$ \\
NPK & $2.34 \pm 0.00 \mathrm{~d}$ & $0.98 \pm 0.00$ & $3.01 \pm 0.04 \mathrm{~b}$ & $0.93 \pm 0.01$ \\
$1 / 2 \mathrm{OMN}$ & $2.15 \pm 0.02 \mathrm{c}$ & $0.98 \pm 0.01$ & $2.89 \pm 0.02 \mathrm{a}$ & $0.94 \pm 0.01$ \\
OM & $2.00 \pm 0.04 \mathrm{~b}$ & $0.96 \pm 0.02$ & $2.91 \pm 0.02 \mathrm{a}$ & $0.94 \pm 0.01$ \\
\hline
\end{tabular}

a. Mean $\pm \operatorname{SD}(n=4)$. Values within the same column followed by the same letter do not differ at $P<0.05$.

Shannon index and the copy numbers of AOB $(r=0.873$, $n=7, P<0.05)$. There were no significant differences in the Evenness among the different treatments.

The DGGE profile of AOA showed a marked difference with the AOB profile and 25 bands were detected in total (Fig. 4). Bands 1-8 appeared at the up part of the gels with higher intensity than other bands. Bands 11 and 13 showed high intensity in NK and PK, but faint in other treatments. Bands 16 and 23 were only detected in the mineral $\mathrm{N}$ fertilizer treatments, and band 19 could not be detected in those treatments receiving organic manure. The Shannon diversity of the organic manure treatments $(1 / 2 \mathrm{OMN}$ and $\mathrm{OM})$ showed a significantly lower value than other treatments (Table 2).

The sequences at $2 \%$ nucleotide cut-offs were used to construct phylogenetic trees with representative sequences retrieved from the GenBank database (Figs 5 and 6). The classification for $A O B$ clusters was tentatively defined in previous studies (Avrahami and Conrad, 2003;
He et al., 2007). All the sequenced clones represented amoA-like sequences that grouped with Nitrosospira and Nitrosomonas-like sequences. Band 1 detected in the $\mathrm{N}$ fertilizer treatments were affiliated with Nitrosospira cluster $3 \mathrm{~b}$, indicating that $\mathrm{N}$ fertilization resulted in a dominance of cluster $3 \mathrm{~b}$. Bands 4 and 6 were grouped in Nitrosospira cluster 3c. In addition, bands 5 and 9 detected in all the treatments were affiliated with the genus Nitrosomonas and belonged to cluster 7. Interestingly, most of the other DGGE bands were affiliated with the genus Nitrosospira cluster 3a. Phylogenetic analysis of archaeal amo $A$ gene showed that all selected clones could be divided into two clusters, i.e. cluster $S$ and cluster M (Fig.6), representing groups dominated by sequences from soil and marine environments respectively (He et al., 2007). The majority of AOA sequences were grouped in cluster $\mathrm{S}$, showing low diversity. Only three DGGE bands, i.e. bands 11-13, were placed in the cluster $\mathrm{M}$.

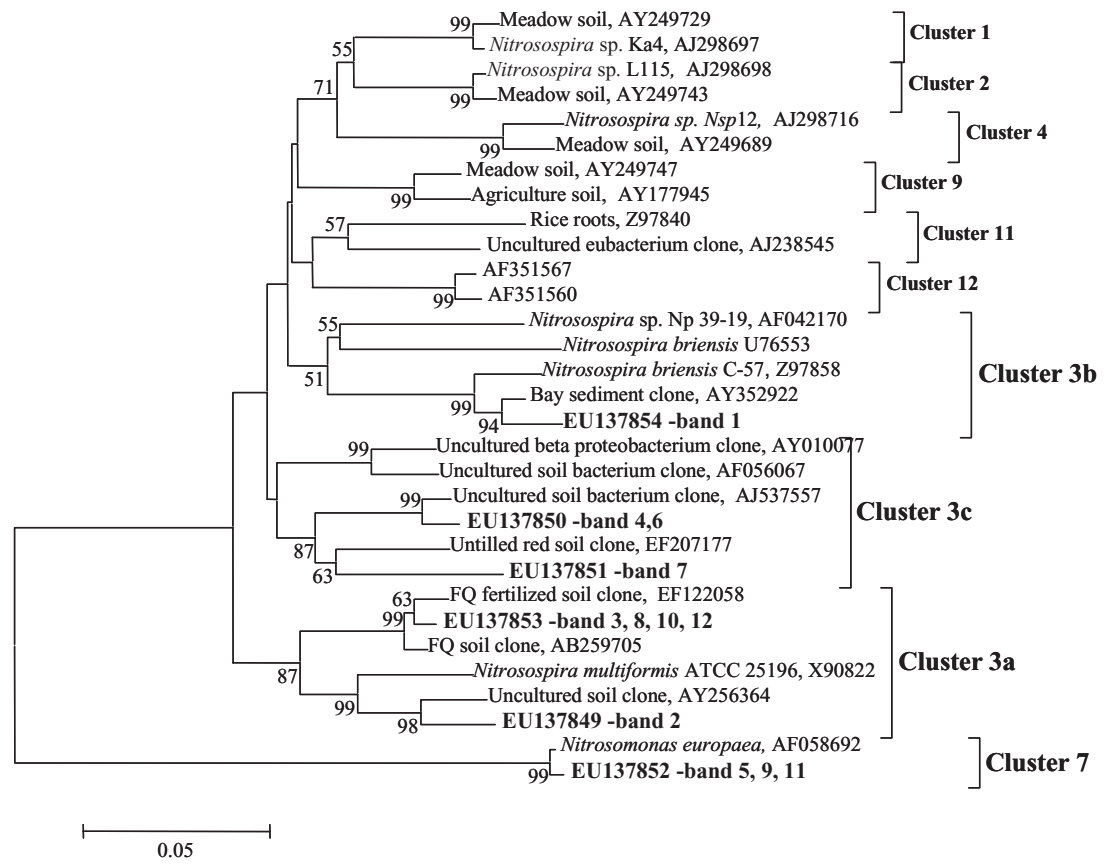

Fig. 5. Phylogenetic relationships among bacterial amo $A$ sequences retrieved from the Fengqiu sandy loam. Designation of the clones in bold includes the following information: accession number in the GenBank with DGGE band position. Bootstrap values $(>50 \%)$ are indicated at branch points. The scale bar represents $5 \%$ estimated sequence divergence. 


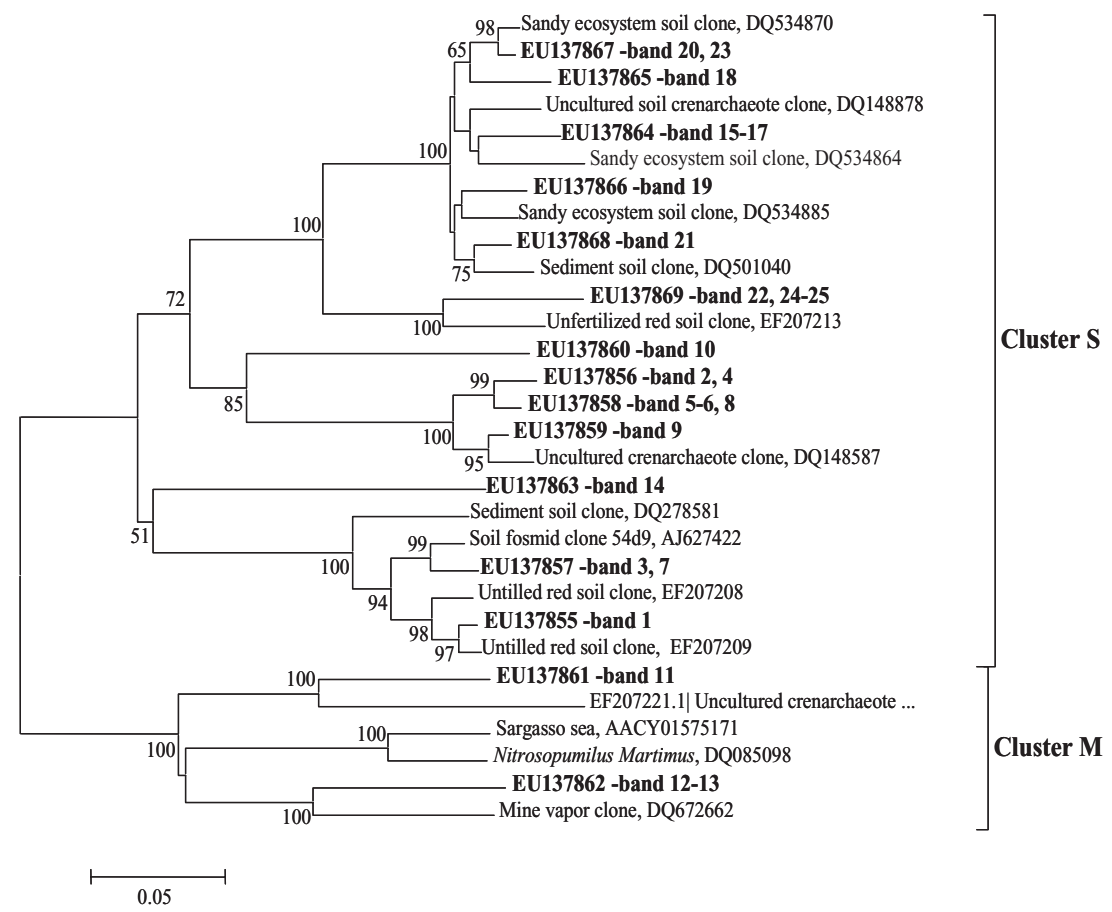

Fig. 6. Phylogenetic relationships among archaeal amoA sequences retrieved from the Fengqiu sandy loam. Designation of the clones in bold includes the following information: accession number in the GenBank with DGGE band position. Bootstrap values $(>50 \%)$ are indicated at branch points. The scale bar represents $5 \%$ estimated sequence divergence.

\section{Discussion}

In this study, we applied real-time PCR to quantify $16 S$ rRNA genes and $a m o A$ genes using the same quantification conditions as in a previous study to compare the effect of fertilization practices on an alkaline soil. The copy numbers of bacterial and archaeal amoA genes measured in this study were both similar to those measured in another arable soil (He et al., 2007). High ratios of AOA to $A O B$ were found in the alkaline soil, providing evidence of their potential importance in nitrification.

Soil $\mathrm{pH}$ had a significantly negative correlation with the bacterial amoA gene copy numbers $(r=0.841, n=7$, $P<0.05$ ), indicating $\mathrm{pH}$ was an important factor in controlling $A O B$ abundance in the soil. The process of ammonia oxidation due to long-term fertilizer inputs leads to a net increased concentration of protons in the environment, which contributes to a lowering of the soil pH (Kowalchuk and Stephen, 2001; Pernes-Debuyser and Tessier, 2004; Enwall et al., 2005). The sampled soil originating from alluvial sediments of the Yellow River was alkaline ( $\mathrm{pH} 8.65$ in CK). The long-term fertilizer application had resulted in a decrease in the soil $\mathrm{pH}$, with the treatments of chemical $\mathrm{N}$ application decreasing to 8.3-8.4 and the $\mathrm{OM}$ and $\mathrm{PK}$ treatments to 8.4-8.5. Although only $0.3 \mathrm{pH}$ units decreased between the treatments of CK and NP, the abundance of $A O B$ increased 22.5 -folds. The reduction in $\mathrm{pH}$ may have increased $\mathrm{AOB}$ growth and abundance. However, no significant correlation was observed between $\mathrm{AOA}$ and $\mathrm{pH}$ in this study, inconsistent with the result that soil $\mathrm{pH}$ played a more important role in $\mathrm{AOA}$ populations as found in acid soil (He et al., 2007). The reason for this inconsistency may be due to the different soil types and the $\mathrm{pH}$ variation ranges. Girvan and colleagues (2003) proposed that soil type is the primary determinant of the bacterial community composition in arable soils, while there is no available information about the relationship of soil type and AOA abundance.

Significantly higher copy numbers of bacterial amoA gene in the $\mathrm{N}$ fertilizer treatments were found compared with the $\mathrm{OM}$ and $\mathrm{CK}$ treatments in this study, indicating $\mathrm{N}$ input could be another key factor for $A O B$ abundance in the natural soil environment. The increasing bioavailability of carbon in the treatments amended with organic manures will naturally promote the growth of heterotrophic bacteria, which could decrease the amount of available ammonia to AOB (Fauci and Dick, 1994; Shi and Norton, 2000). A higher ratio of nitrate to ammonium in those mineral $\mathrm{N}$ fertilizer treatments also indicated their preference for these conditions due to a significant correlation between nitrate content and AOB $(r=0.805, n=7$, $P<0.05)$. The proportion of $A O B$ to total bacteria detected in the mineral $\mathrm{N}$ fertilizer treatments, ranging from $0.012 \%$ to $0.060 \%$, was significantly higher than those in the CK treatment $(0.003 \%)$. Although AOB varied significantly in the abundance with different treatments, they were just a small fraction of the total bacterial population. However, this small fraction changed sensitively in response to the $\mathrm{N}$ fertilizer application, providing a potential indicator of such change. Therefore, AOB were more sensitive than 
total bacteria as an indicator to index nitrogen cycling in the soil (Kowalchuk and Stephen, 2001). There was a significant correlation between PNR and AOB abundance ( $r=0.773, n=7, P<0.05$ ), but not with the AOA. This suggested that $A O B$ abundance could be predicted by PNR with high confidence (Bernhard et al., 2007).

No significant differences in AOA abundance were observed among the different treatments, suggesting that $\mathrm{N}$ fertilizer input may not be a substantial factor for the AOA community in the alkaline soil or the amount of ammonia required for detectable changes in AOA abundance will be significantly greater than for the less abundant AOB. Previous studies demonstrated great abundances of AOA in marine environment which have an alkaline pH (Wuchter et al., 2006; Mincer et al., 2007; Coolen et al., 2007). A study on the Black Sea has demonstrated an abundance of putative nitrifying archaea at very low oxygen levels and might form an important source of nitrite for the anammox reaction (Coolen et al., 2007). The higher numbers of AOA detected in soil or marine environment may play a potential role in the global nitrogen cycle. In estuarine sediments from Bahía del Tóbari (Mexico), AOA communities from the interior of the estuary to the mouths of the estuary showed spatial structuring, and the distribution of these two archaeal amoA ecotypes was associated with group 1.1a and 1.1b Crenarchaeota (Beman and Francis, 2006). These findings represent the first detailed examination of archaeal amoA diversity in estuarine sediments, and reflected their potential activity in nitrification.

The difference in the $A O B$ abundance we observed may be due to the shifts of community composition or community density. Polymerase chain reaction-DGGE approaches have been used to analyse the community structure of AOB and AOA (Kowalchuk et al., 1997; Freitag and Prosser, 2003; Wuchter et al., 2006). There was a significantly positive correlation between AOB abundance and Shannon index $(r=0.873, \quad n=7$, $P<0.05$ ), which implied that the change of AOB abundance could be partly due to the shifts of the community composition. Moreover, the DGGE patterns of the $\mathrm{N}$ fertilizer treatments showed an increase in the diversity of the AOB community. Similar results have been reported by Chu and colleagues (2007) who used a modified primer pair for PCR-DGGE analysis in the same soil. Addition of $\mathrm{N}$ fertilizer showed no evidence for a community shift of AOB after 4 weeks (Avrahami et al., 2002) or 6 weeks of incubation (Mendum et al., 1999), but a shift was observed after 16 weeks (Avrahami and Conrad, 2003). Horz and colleagues (2004) also reported a significant change in the structure of $\mathrm{AOB}$ after increased nitrogen deposition for 2 years. Obviously, AOB community composition can be consistently altered by fertilization, especially $\mathrm{N}$ fertilizer application, and affects the potential ammonia oxidation. There was no difference in the AOA DGGE patterns among the different fertilization treatments, indicating no differences in AOA community structure in this study. However, a pronounced difference in AOA composition was observed in acid soil ( $\mathrm{He}$ et al., 2007). It is likely therefore that the changes of AOA abundance and community in the alkaline soil are not as sensitive as in the acid soil, due to its less $\mathrm{pH}$ variation than the acid soil under the different fertilization treatments.

The phylogeny of the amoA gene was found to correspond largely to the phylogeny of the 16S rRNA gene in AOB (Purkhold et al., 2000; Aakra et al., 2001; Avrahami et al., 2003). Phylogenetic analysis of bacterial amoA sequences suggested that the soil $A O B$ was dominated by Nitrosospira-like sequences, with Nitrosomonas-like sequences also present. Most sequences in this study were affiliated with Nitrosospira cluster 3, which has been detected as the dominant ammonia-oxidizer group in a number of arable soils (Phillips et al., 2000; He et al., 2007). However, the presence of Nitrosomonas-like sequences in this study is inconsistent with some previous studies that only Nitrosospira-like sequences are detected (Bruns et al., 1999; Webster et al., 2002; Chu et al., 2007). Nitrosomonas species have been detected in manure-treated wetland (Ibekwe et al., 2003), enrichment cultures (Stephen et al., 1996), wastewater treatment systems (Logemann et al., 1998) and limed acid forest soil (Carnol et al., 2002). These results provide further evidence for their preference for high-ammonia and high-pH environments (Kowalchuk and Stephen, 2001). The majority of the archaeal amo $A$ sequences from this study were placed within cluster $S$. In addition, sequences affiliated with cluster $M$ were also obtained in all treatments, suggesting that the soil sequences may have a similar original with marine sequences.

This study demonstrated statistically significantly higher copy numbers of bacterial amoA gene in the $\mathrm{N}$ mineral fertilizer treatments than in the CK treatment, and DGGE patterns also showed the community shifts among the different fertilization treatments. These results are consistent with a number of studies that $A O B$ provide a good index in response to the varying environment (Kowalchuk and Stephen, 2001). The higher numbers of archaeal amo $A$ genes than bacterial $a m o A$ genes among the treatments indicate that AOA may play a potential role in the global nitrogen cycle (Nicol and Schleper, 2006; Francis et al., 2007). Intriguingly, the abundance and diversity of AOA showed no significant difference under different fertilization treatments. It remains to be shown whether the higher numbers of $\mathrm{AOA}$ in soil also contribute to the nitrification. Thus, we hypothesize that soil type is the key factor in community change for AOA, and further studies should be performed to determine how soil type or other characteristics affect the activity and structure of AOA. 
Furthermore, the long-term fertilization practices had a significant impact on soil conditions, and their effects on the ammonia oxidizers ( $A O B$ and $A O A$ ) provide an indicator for assessing soil sustainable management.

\section{Experimental procedures}

\section{Study site and sampling}

The long-term field experiment was located in the Fengqiu State Key Experimental Station for Ecological Agriculture $\left(35^{\circ} 00^{\prime} \mathrm{N}, 114^{\circ} 24^{\prime} \mathrm{E}\right)$, Henan province, northern China. The area had an annual precipitation of $605 \mathrm{~mm}$ and a mean annual temperature of $13.9^{\circ} \mathrm{C}$. The soil was a sandy loam (clay $11 \%$, silt $72 \%$ and sand $17 \%$ ) derived from alluvial sediments of the Yellow River and classified as aquic inceptisol. The fertilization experiment was established in September 1989 with a wheat-maize rotation system including seven treatments with four replicates (plot area $9.5 \times 5 \mathrm{~m}^{2}$ ) for each treatment in a randomized plot design (Meng et al., 2005). The seven treatments were control without fertilizer (CK); those with combinations of fertilizer nitrogen (N), phosphorus (P) and potassium (K): NP, NK, PK, NPK; half chemical fertilizers NPK plus half organic manure $(1 / 2 \mathrm{OMN})$; and organic manure (OM). Fertilizers $\mathrm{N}, \mathrm{P}$ and $\mathrm{K}$ were applied in the form of urea (300 $\mathrm{kg} \mathrm{N} \mathrm{ha}^{-1}$ per year), super phosphate (150 $\mathrm{kg} \mathrm{P}_{2} \mathrm{O}_{5} \mathrm{ha}^{-1}$ per year) and potassium sulfate $\left(300 \mathrm{~kg} \mathrm{~K}_{2} \mathrm{O} \mathrm{ha}^{-1}\right.$ per year). The organic manure was a composted mixture of wheat straw, oil cake and cotton cake in a ratio of 100:40:45 (Meng et al., 2005). Soil samples were collected from 0 to $20 \mathrm{~cm}$ surface soil in April 2006 and April 2007 by taking 12 soil cores (c. $5 \mathrm{~cm}$ diameter) from each plot and mixing them to form one composite sample. All samples were passed through a $2.0 \mathrm{~mm}$ sieve and subsamples were stored at $-80^{\circ} \mathrm{C}$ for DNA extraction.

\section{Soil chemical analysis and potential nitrification rate}

Soil $\mathrm{pH}$ was determined with a soil to distilled water ratio of 1:2.5, and soil organic carbon was determined by $\mathrm{K}_{2} \mathrm{Cr}_{2} \mathrm{O}_{7}$ oxidation-reduction titration method. Nitrate and ammonium were extracted with $2 \mathrm{M} \mathrm{KCl}$ and determined by a Continuous Flow Analyser (SAN++, Skalar, Holand). Potential nitrification rates were measured using the chlorate inhibition method (Kurola et al., 2005). Briefly, $5.0 \mathrm{~g}$ of fresh soil was added to $50 \mathrm{ml}$ centrifuge tubes containing $20 \mathrm{ml}$ of phosphate buffer solution (PBS) (g l-1: $\mathrm{NaCl}, 8.0 ; \mathrm{KCl}, 0.2 ; \mathrm{Na}_{2} \mathrm{HPO}_{4}, 0.2$; $\mathrm{NaH}_{2} \mathrm{PO}_{4}, 0.2 ; \mathrm{pH} 7.4$ ) with $1 \mathrm{mM}\left(\mathrm{NH}_{4}\right)_{2} \mathrm{SO}_{4}$. Potassium chlorate with a final concentration of $10 \mathrm{mM}$ was added to the tubes to inhibit nitrite oxidation. The suspension was incubated in a dark incubator at $25^{\circ} \mathrm{C}$ for $24 \mathrm{~h}$, after that nitrite was extracted with $5 \mathrm{ml}$ of $2 \mathrm{M} \mathrm{KCl}$ and determined spectrophotometrically at $540 \mathrm{~nm}$ with $\mathrm{N}$-(1-naphthyl) ethylenediamine dihydrochloride.

\section{DNA extraction}

Nucleic acids were extracted from $0.5 \mathrm{~g}$ of fresh soil using a MoBio UltraClean ${ }^{\mathrm{TM}}$ soil DNA isolation kit (San Diego, CA) according to the manufacturer's protocol with a minor modification (He et al., 2007). DNA was eluted with $50 \mu \mathrm{l}$ of solution S5 (MoBio Laboratories, cat. No. 12800-100) and stored at $-20^{\circ} \mathrm{C}$ before use.

\section{Real-time PCR assay and PCR amplification for DGGE}

Real-time PCR was performed on an iCycler iQ 5 thermocycler (Bio-Rad). For all real-time PCR assays, TaqMan probes were labelled at the $5^{\prime}$ end with the reporter dye FAM (6-carboxy-fluorescein) and at the $3^{\prime}$ end with the quencher dye TAMRA (6-carboxy-tetramenthylrhodamine) (Takara Bio, Otsu, Shiga, Japan). Primer and TaqMan probe concentrations were optimized with the final concentrations listed in Table 3. The DNA was diluted 10-fold and bovine serum albumin (BSA) was added to reduce the interference of humic acid in the PCR (He et al., 2005). Bacterial amoA genes were quantified using the primers $A 189 / a m o A-2 R^{\prime}$ and the probe A337 (Okano et al., 2004) with HotStarTaq DNA Polymerase (Qiagen, Valencia, CA) in a $25 \mu \mathrm{l}$ reaction mixture containing $1 \times$ PCR buffer, $2.0 \mathrm{mM} \mathrm{MgCl} 2,200 \mu \mathrm{M}$ of each dNTP, $2.5 \mathrm{U}$ HotStarTaq DNA polymerase. Quantification of bacterial $16 \mathrm{~S}$ rRNA gene using primers BACT1369F/PROK1541R and probe TM1389F (Table 3, Suzuki et al., 2000) was performed using iQ $^{\text {TM }}$ Supermix (Bio-Rad). Primers Arch-amoAF/ArchamoAR (Francis et al., 2005) was used for quantification of archaeal $a m o A$ gene with SYBR $^{\circledR}$ Premix Ex Taq ${ }^{\text {TM }}$ (TaKaRa).

Real-time PCR assays were performed with protocols for each target group as shown in Table 3. For bacterial amoA gene assay, an initial procedure at $95^{\circ} \mathrm{C}$ for 15 min was used to activate the HotStarTaq DNA Polymerase activity. In order to obtain lower background fluorescence signal in the negative controls due to host DNA carryover in the cloned DNA polymerase preparations (Suzuki et al., 2000), 35 cycles were used for the bacterial 16S rRNA amplification. Assays for the other two target groups were run using 40 cycles. Assay for the archaeal amoA gene was performed with a four-step thermoprofile, and fluorescence intensity was measured at $83^{\circ} \mathrm{C}$ (above the melting point of primer dimers). Following the four temperature steps, a melting curve analysis was performed to confirm PCR product specificity after amplification by measuring fluorescence continuously as the temperature increased from $55^{\circ} \mathrm{C}$ to $95^{\circ} \mathrm{C}$. Data analysis was carried out with iCycler software (version 1.0.1384.0 CR). The parameter $\mathrm{Ct}$ (threshold cycle) was determined as the cycle number at which a statistically significant increase in the reporter fluorescence was detected.

Standard curves for real-time PCR assays were developed as described previously (He et al., 2007). Briefly, the bacterial amoA gene, bacterial 16S rRNA gene and archaeal amoA gene were PCR-amplified from extracted DNA with the primers A189/amoA-2R', 27F/1492R (Lane, 1991) and archamoAF/arch-amoAR, respectively, and the PCR products were cloned into the pGEM-T Easy Vector (Promega). Plasmids used as standards for quantitative analyses were extracted from the correct insert clones of each target gene. The plasmid DNA concentration was determined on a Nanodrop® ND-1000 UV-Vis Spectrophotometer (NanoDrop Technologies) and the copy numbers of target genes were calculated directly from the concentration of the extracted plasmid DNA. Ten-fold serial dilutions of a known copy 


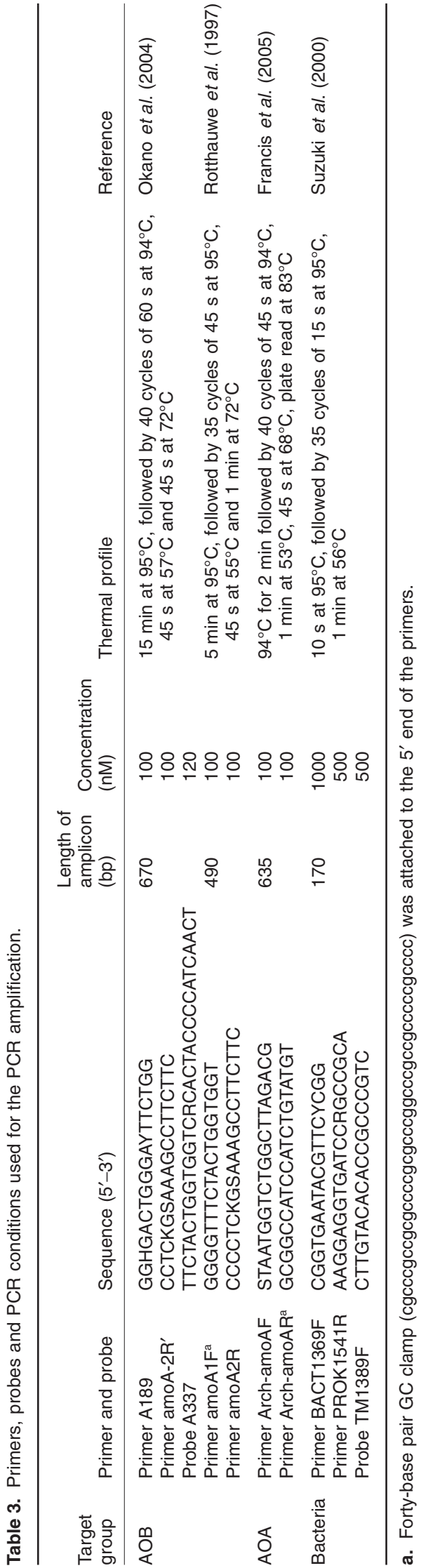

number of the plasmid DNA were subjected to real-time PCR assay in triplicate to generate an external standard curve as the previous study (He et al., 2007).

For DGGE analysis, the primers used for bacterial and archaeal amoA gene amplification were amoA1F-GC/ amoA2R and arch-amoAF/arch-amoAR-GC (Table 3) respectively. Amplification was performed in $50 \mu \mathrm{l}$ reaction mixtures including $1 \times$ PCR buffer, $3.0 \mathrm{mM} \mathrm{MgCl} 2,400 \mu \mathrm{M}$ each dNTP, $2.5 \mathrm{U}$ Taq DNA polymerase (TaKaRa) plus primers and BSA. The thermal profile used for amplification of archaeal amoA gene was the same as used for the bacterial amo $A$ gene amplification as listed in Table 3 and 35 cycles were used.

\section{Denaturing gradient gel electrophoresis analysis}

Denaturing gradient gel electrophoresis analysis of amoA PCR products was performed with the DCode Universal Mutation Detection System (Bio-Rad Laboratories, Hercules, USA). Polymerase chain reaction products of bacterial and archaeal amoA genes were loaded onto polyacrylamide gradient gels with a denaturing gradient of $40-65 \%$ and $20-45 \%$ ( $100 \%$ denaturant contains $7 \mathrm{M}$ urea and $40 \%$ formamide) respectively. Electrophoreses were run at $120 \mathrm{~V}$ for $8 \mathrm{~h}$ and $6 \mathrm{~h}$ for $\mathrm{AOB}$ and $\mathrm{AOA}$ respectively. The gels were stained with 1:10000 SYBR Gold Nucleic Acid Gel Stain (Invitrogen 20 Molecular Probes, Eugene, USA) for 30 min according to the manufacturer's instructions, scanned by a GBOX/HR-E-M (Syngene, UK) and analysed using the software Quantity One (Bio-Rad Laboratories).

\section{Cloning and sequencing}

Numbered bands in the DGGE gel and other bands with the same mobility were excised for clone and sequencing analysis. Initial experiment found that the bands with the same mobility in a DGGE gel had highly similar (>98\%) nucleotide sequences. The dominant bands in the DGGE gel were excised and suspended in $50 \mu \mathrm{l}$ of Tris- $\mathrm{HCl}$ buffer $(\mathrm{pH} 8.0)$ for $12 \mathrm{~h}$, and reamplified with the primers amoA1F/ amoA2R and arch-amoAF/arch-amoAR. The purified reamplified PCR products were ligated into the pGEM-T Easy Vector (Promega, Madison, WI, USA), and the resulting ligation mix transformed into Escherichia coli JM109 competent cells following the instructions of the manufacturer. The positive clones were amplified using the above primers with GC clamp and checked by DGGE. The correct one was selected for sequencing.

\section{Phylogenetic analysis}

The sequences were aligned with BLAST search program and similarity analysis was performed with DNAStar and DNAMAN version 4.0. Phylogenetic analyses were conducted using MEGA version 3.0 (Kumar et al., 2004; He et al., 2006) and the neighbour-joining tree was constructed using Kimura 2-parameter distance with 1000 replicates to produce Bootstrap values. UPGMA algorithms were used to cluster the DGGE patterns. The Shannon diversity index $H$ and Evenness index $E$ were used to calculate the band 
pattern diversity of $\mathrm{AOB}$ and $\mathrm{AOA}$ based on the following equations:

$$
H=-\sum_{i=1}^{S} p_{i} \ln p_{i}=-\sum_{i=1}^{S}\left(N_{i} / N\right) \ln \left(N_{i} / N\right) \quad E=H / H_{\max }=H / \ln S
$$

where $N_{i}$ is the abundance of the ith ribotype, $N$ is the total abundance of all ribotypes in the sample (lane of DGGE gels) and $S$ is the number of ribotypes.

\section{Statistical analysis}

Copy numbers were log-transformed as needed to normalize the distributions prior to statistical analysis. All statistical analyses were performed using SPSS version 11.5, and one-way analysis of variance (ANOVA) followed by S-N-K-test was used to check for quantitative differences between treatments. $P<0.05$ was considered to be statistically significant.

\section{Sequence accession numbers}

All amoA gene sequences have been deposited in the GenBank nucleotide sequence database under Accession No. EU137849 to EU137854 for AOB and EU137855 to EU137869 for AOA.

\section{Acknowledgements}

We appreciate Dr Nicol Graeme for his helpful comments and English improvements. This work was supported by the National Basic Research Program of China (2005CB121105), Chinese Academy of Sciences (KZCX1-YW-0603, KZCX2YW-408) and the Natural Science Foundation of China (50621804, 40571082).

\section{References}

Aakra, A., Utaker, J.B., and Nes, I.F. (2001) Comparative phylogeny of the ammonia monooxygenase subunit $A$ and 16S rRNA genes of ammonia-oxidizing bacteria. FEMS Microbiol Lett 205: 237-242.

Avrahami, S., and Conrad, R. (2003) Patterns of community change among ammonia oxidizers in meadow soils upon long-term incubation at different temperatures. Appl Environ Microbiol 69: 6152-6164.

Avrahami, S., Conrad, R., and Braker, G. (2002) Effect of soil ammonium concentration on $\mathrm{N}_{2} \mathrm{O}$ release and on the community structure of ammonia oxidizers and denitrifiers. Appl Environ Microbiol 68: 5685-5692.

Avrahami, S., Liesack, W., and Conrad, R. (2003) Effects of temperature and fertilizer on activity and community structure of soil ammonia oxidizers. Environ Microbiol 5: 691-705.

Beman, J.M., and Francis, C.A. (2006) Diversity of ammoniaoxidizing archaea and bacteria in the sediments of a hypernutrified subtropical estuary: Bahía del Tóbari, Mexico. Appl Environ Microbiol 72: 7767-7777.

Bernhard, A.E., Tucker, J., Giblin, A.E., and Stahl, D.A. (2007) Functionally distinct communities of ammonia- oxidizing bacteria along an estuarine salinity gradient. Environ Microbiol 9: 1439-1447.

Bruns, M.A., Stephen, J.R., Kowalchuk, G.A., Prosser, J.I., and Paul, E.A. (1999) Comparative diversity of ammonia oxidizer 16S rRNA gene sequences in native, tilled, and successional soils. Appl Environ Microbiol 65: 2994-3000.

Carnol, M., Kowalchuk, G.A., and De Boer, W. (2002) Nitrosomonas europaea-like bacteria detected as the dominant beta-subclass Proteobacteria ammonia oxidisers in reference and limed acid forest soils. Soil Biol Biochem 34: 1047-1050.

Chu, H.Y., Fujii, T., Morimoto, S., Lin, X.G., Yagi, K., Hu, J.L., and Zhang, J.B. (2007) Community structure of ammoniaoxidizing bacteria under long-term application of mineral fertilizer and organic manure in a sandy loam soil. Appl Environ Microbiol 73: 485-491.

Coolen, M.J.L., Abbas, B., van Bleijswijk, J., Hopmans, E.C., Kuypers, M.M.M., Wakeham, S.G., and Damste, J.S.S. (2007) Putative ammonia-oxidizing Crenarchaeota in suboxic waters of the Black Sea: a basin-wide ecological study using $16 \mathrm{~S}$ ribosomal and functional genes and membrane lipids. Environ Microbiol 9: 1001-1016.

Enwall, K., Philippot, L., and Hallin, S. (2005) Activity and composition of the denitrifying bacterial community respond differently to long-term fertilization. Appl Environ Microbiol 71: 8335-8343.

Fauci, M.F., and Dick, R.P. (1994) Soil microbial dynamics: short- and long-term effects of inorganic and organic nitrogen. Soil Sci Soc Am J 58: 801-806.

Francis, C.A., Roberts, K.J., Beman, J.M., Santoro, A.E., and Oakley, B.B. (2005) Ubiquity and diversity of ammoniaoxidizing archaea in water columns and sediments of the ocean. Proc Natl Acad Sci USA 102: 14683-14688.

Francis, C.A., Beman, J.M., and Kuypers, M.M.M. (2007) New processes and players in the nitrogen cycle: the microbial ecology of anaerobic and archaeal ammonia oxidation. ISME J 1: 19-27.

Freitag, T.E., and Prosser, J.I. (2003) Community structure of ammonia-oxidizing bacteria within anoxic marine sediments. Appl Environ Microbiol 69: 1359-1371.

Girvan, M.S., Bullimore, J., Pretty, J.N., Osborn, A.M., and Ball, A.S. (2003) Soil type is the primary determinant of the composition of the total and active bacterial communities in arable soils. Appl Environ Microbiol 69: 1800-1809.

He, J.Z., Xu, Z.H., and Hughes, J. (2005) Pre-lysis washing improves DNA extraction from a forest soil. Soil Biol Biochem 37: 2337-2341.

He, J.Z., Xu, Z.H., and Hughes, J. (2006) Molecular bacterial diversity of a forest soil under residue management regimes in subtropical Australia. FEMS Microbiol Ecol 55: 38-47.

He, J.Z., Shen, J.P., Zhang, L.M., Zhu, Y.G., Zheng, Y.M., Xu, M.G., and Di, H.J. (2007) Quantitative analyses of the abundance and composition of ammonia-oxidizing bacteria and ammonia-oxidizing archaea of a Chinese upland red soil under long-term fertilization practices. Environ Microbiol 9: 2364-2374.

Horz, H.P., Barbrook, A., Field, C.B., and Bohannan, B.J.M. (2004) Ammonia-oxidizing bacteria respond to multifactorial global change. Proc Natl Acad Sci USA 101: 1513615141. 
Ibekwe, A.M., Grieve, C.M., and Lyon, S.R. (2003) Characterization of microbial communities and composition in constructed dairy wetland wastewater effluent. Appl Environ Microbiol 69: 5060-5069.

Könneke, M., Bernhard, A.E., de la Torre, J.R., Walker, C.B., Waterbury, J.B., and Stahl, D.A. (2005) Isolation of an autotrophic ammonia-oxidizing marine archaeon. Nature 437: 543-546.

Kowalchuk, G.A., and Stephen, J.R. (2001) Ammoniaoxidizing bacteria: a model for molecular microbial ecology. Annu Rev Microbiol 55: 485-529.

Kowalchuk, G.A., Stephen, J.R., DeBoer, W., Prosser, J.I., Embley, T.M., and Woldendorp, J.W. (1997) Analysis of ammonia-oxidizing bacteria of the beta subdivision of the class Proteobacteria in coastal sand dunes by denaturing gradient gel electrophoresis and sequencing of PCRamplified 16S ribosomal DNA fragments. Appl Environ Microbiol 63: 1489-1497.

Kumar, S., Tamura, K., and Nei, M. (2004) MEGA3: integrated software for molecular evolutionary genetics analysis and sequence alignment. Brief Bioinform 5: 150-163.

Kurola, J., Salkinoja-Salonen, M., Aarnio, T., Hultman, J., and Romantschuk, M. (2005) Activity, diversity and population size of ammonia-oxidising bacteria in oil-contaminated landfarming soil. FEMS Microbiol Lett 250: 33-38.

Lane, D.J. (1991) 16S/23S rRNA sequencing. In Nucleic Acid Techniques in Bacterial Systematics. Stackebrandt, E., and Goodfellow, M. (eds). New York, USA: John Wiley \& Sons, pp. 115-175.

Leininger, S., Urich, T., Schloter, M., Schwark, L., Qi, J., Nicol, G.W., et al. (2006) Archaea predominate among ammonia-oxidizing prokaryotes in soils. Nature 442: $806-$ 809.

Logemann, S., Schantl, J., Bijvank, S., van Loosdrecht, M., Kuenen, J.G., and Jetten, M. (1998) Molecular microbial diversity in a nitrifying reactor system without sludge retention. FEMS Microbiol Ecol 27: 239-249.

Mendum, T.A., Sockett, R.E., and Hirsch, P.R. (1999) Use of molecular and isotopic techniques to monitor the response of autotrophic ammonia-oxidizing populations of the beta subdivision of the class Proteobacteria in arable soils to nitrogen fertilizer. Appl Environ Microbiol 65: 4155-4162.

Meng, L., Ding, W., and Cai, Z. (2005) Long-term application of organic manure and nitrogen fertilizer on $\mathrm{N}_{2} \mathrm{O}$ emissions, soil quality and crop production in a sandy loam soil. Soil Biol Biochem 37: 2037-2045.

Mincer, T.J., Church, M.J., Taylor, L.T., Preston, C., Kar, D.M., and DeLong, E.F. (2007) Quantitative distribution of presumptive archaeal and bacterial nitrifiers in Monterey Bay and the North Pacific Subtropical Gyre. Environ Microbiol 9: 1162-1175.

Nicol, G.W., and Schleper, C. (2006) Ammonia-oxidising Crenarchaeota: important players in the nitrogen cycle? Trends Microbiol 14: 207-212.

Okano, Y., Hristova, K.R., Leutenegger, C.M., Jackson, L.E., Denison, R.F., Gebreyesus, B., et al. (2004) Application of real-time PCR to study effects of ammonium on population size of ammonia-oxidizing bacteria in soil. Appl Environ Microbiol 70: 1008-1016.

Pernes-Debuyser, A., and Tessier, D. (2004) Soil physical properties affected by long-term fertilization. Eur J Soil Sci 55: 505-512.

Phillips, C.J., Harris, D., Dollhopf, S.L., Gross, K.L., Prosser, J.I., and Paul, E.A. (2000) Effects of agronomic treatments on structure and function of ammonia-oxidizing communities. Appl Environ Microbiol 66: 5410-5418.

Purkhold, U., Pommerening-Roser, A., Juretschko, S., Schmid, M.C., Koops, H.P., and Wagner, M. (2000) Phylogeny of all recognized species of ammonia oxidizers based on comparative $16 \mathrm{~S}$ rRNA and amoA sequence analysis: implications for molecular diversity surveys. Appl Environ Microbiol 66: 5368-5382.

Rotthauwe, J.H., Witzel, K.P., and Liesack, W. (1997) The ammonia monooxygenase structural gene amo $A$ as a functional marker: molecular fine-scale analysis of natural ammonia-oxidizing populations. Appl Environ Microbio/ 63: 4704-4712.

Schmidt, C.S., Hultman, K.A., Robinson, D., Killham, K., and Prosser, J.I. (2007) PCR profiling of ammonia-oxidizer communities in acidic soils subjected to nitrogen and sulphur deposition. FEMS Microbiol Ecol 61: 305-316.

Shi, W., and Norton, J.M. (2000) Microbial control of nitrate concentrations in an agricultural soil treated with dairy waste compost or ammonium fertilizer. Soil Biol Biochem 32: 1453-1457.

Sigunga, D.O., Janssen, B.H., and Oenema, O. (2002) Ammonia volatilization from vertisols. Eur J Soil Sci 53: 195-202.

Stephen, J.R., McCaig, A.E., Smith, Z., Prosser, J.I., and Embley, T.M. (1996) Molecular diversity of soil and marine 16S rRNA gene sequences related to beta-subgroup ammonia-oxidizing bacteria. Appl Environ Microbiol 62: 4147-4154.

Suzuki, M.T., Taylor, L.T., and DeLong, E.F. (2000) Quantitative analysis of small-subunit rRNA genes in mixed microbial populations via 5'-nuclease assays. Appl Environ Microbiol 66: 4605-4614.

Treusch, A.H., Leininger, S., Kletzin, A., Schuster, S.C., Klenk, H.P., and Schleper, C. (2005) Novel genes for nitrite reductase and Amo-related proteins indicate a role of uncultivated mesophilic crenarchaeota in nitrogen cycling. Environ Microbiol 7: 1985-1995.

Venter, J.C., Remington, K., Heidelberg, J.F., Halpern, A.L., Rusch, D., Eisen, J.A., et al. (2004) Environmental genome shotgun sequencing of the Sargasso sea. Science 304: 66-74.

Webster, G., Embley, T.M., and Prosser, J.I. (2002) Grassland management regimens reduce small-scale heterogeneity and species diversity of $\beta$-Proteobacterial ammonia oxidizer populations. Appl Environ Microbiol 68: 20-30.

Wuchter, C., Abbas, B., Coolen, M.J.L., Herfort, L., van Bleijswijk, J., Timmers, P., et al. (2006) Archaeal nitrification in the ocean. Proc Natl Acad Sci USA 103: 1231712322. 